\title{
Does Balance of Payments Constrained Growth Model Hold in Saudi Arabia?
}

\author{
Mohammed Al- Mahish *
}

\begin{abstract}
The paper aims to examine whether or not the balance of payments constrained growth model holds in Saudi Arabia. Also, the paper seeks to examine whether the balance of payments constrained growth model can predict Saudi Arabia's real GDP growth rate. In the longrun, the estimation results show that Saudi Arabia has an elastic income elasticity of demand for imports and an inelastic price elasticity of demand for imports. The McCombie test shows that the hypothetical income elasticity of demand for imports, which assumes balance of payments is in equilibrium, is not significantly different from the estimated income elasticity of demand for imports. The test was conducted by assuming that the terms of trade remains constants in the long-run and by including terms of trade effect. As a result, the paper provides evidence proving the validity of the Thirlwall's model in Saudi Arabia. Furthermore, the paper shows that Saudi Arabia's real GDP growth rate behaves in a similar fashion to the growth rate predicted by the balance of payments constrained growth model. In addition, the paper has provided an overview of Saudi Arabia's 2030 vision and how the balance of payments constrained growth model's recommendation can fit into Saudi Arabia's 2030 vision.
\end{abstract}

Keywords: Balance of payments constrained growth model; economic growth; Saudi Arabia.

\section{Introduction}

The theory of the balance of payments constrained growth (BOPCG) states that the primary constraint of a country's economic growth rate is its balance of payment position (Gouvêa \& Lima, 2010).

The model gained popularity in the economic literature due to its simplicity and validity. Lanzafame (2014); Thirlwall and Hussain (1982) model using the following import and export demand functions formulas:

$$
\begin{aligned}
X_{t} & =\left(P_{d t} / P_{f t}\right)^{\eta} Z_{t}^{\epsilon} \\
M_{t} & =\left(P_{d t} / P_{f t}\right)^{\psi} Y_{t}^{\pi}
\end{aligned}
$$

\footnotetext{
*Institutional Affiliation: Department of Applied Economics, King Faisal University, 50184.

E-mail: mohammed_9m@yahoo.com
} 
Where $P_{d}$ is the local price of exports and $P_{f}$ is the international price of import (both measured in one currency). $\mathrm{X}$ is export, $\mathrm{M}$ is import, $\mathrm{Z}$ is the world income, $\mathrm{Y}$ is national income, $\eta$ and $\psi$ are price elasticities of exports and imports, and $\epsilon$ and $\pi$ are income elasticities of exports and imports,respectively. By log-linearizing (1) and (2), differentiating with respect to time, and setting (1) equal to (2), we obtain the following equilibrium condition:

$$
\eta\left(p_{d t}-p_{f t}\right)+\eta z_{t}=\theta\left(p_{d t}-p_{f t}\right)+\pi y_{t}
$$

The variables are expressed in lowercase letters to denote growth rates. By solving for y and assuming relative prices (expressed in single currency) stay constant in the long-run (Thirlwall \& Hussain, 1982).

$$
Y_{B O P}=\frac{\epsilon z_{t}}{\pi}
$$

(3) can also be written as

$$
Y_{B O P}=\frac{x_{t}}{\pi}
$$

Where $x$ is the export growth rate, and $Y_{B O P}$ is the growth rate consistent with the balance of payments equilibrium. Thirlwall's model is recognized in the economic literature as the dynamic Harrod trade multiplier (Thirlwall, 2011).

Tharnpanich and McCombie (2013); McCombie (1992) expressed the balance of payments equilibrium growth rate that includes terms of trade effect as follow:

$$
Y_{B O P}=\frac{\left.x_{t}+(1+\psi)\left(p_{d t}-p_{f t}-e_{t}\right)\right)}{\pi}
$$

Where, $p d, p f$, and $e$ are the growth rates of local price, international price, and exchange rate, respectively.

This paper aims to examine whether the BOPCG model holds for the case of Saudi Arabia's economy. Also, the paper aims to evaluate whether or not growth rate for-casted by the BOPCG model can mimic Saudi Arabia's real GDP growth rate. The paper also seeks to provide an overview of Saudi Arabia's 2030 vision and its objectives.

\section{Literature Review}

Empirical analysis on the BOPCG model in economic literature were conducted in developing and developed countries. The model applications in economic research examined both the basic model and the extended model. The extension to the model includes, but is not limited to, capital flows (Thirlwall \& Hussain, 1982), unbalanced trade and debt accumulation (Barbosa-Filho, 2012), interest payment (Moreno-Brid, 2003), net transfers (Alleyne \& Francis, 2008), internal and external imbalances (Soukiazis, Cerqueira, \& Antunes, 2014), convergence term (Garcimartin, 
Alonso, \& Rivas, 2014), private balance-constrained growth rate and public balance constrained growth rate (Bajo-Rubio, 2014), and business cycles. Garcimartin, Kvedaras, and Rivas (2016) Application of the model for the US economy found a supportive conclusion of the model in the US. Atesoglu (1993) concludes that the role of relative prices in the determination of balance of payments performance is a trivial role

Conversely, real income plays a major role in correcting disequilibrium in the balance of payments. Atesoglu (1997) finds that real income and real exports are cointegrated in the long-run for the period of 1931-1994, proving the validity of the BOPCG model. Hieke (1997) states that the omission of relative prices in the import demand function may lead to quantitative bias and may result in an incorrect model specification. Halicioglu (2012) finds a supportive evidence that the BOPCG model holds in Turkey. The author shows that on average the forecasted growth rate of income based on the BOPCG model is close to the actual growth rate of income. Gökçe and Çankal (2013) test the model in Turkey. The authors find the log of GDP and the log of export have one cointegrating vector based on Johansen cointegration analysis. The authors indicate that a statistically significant and positive association between the log of GDP and the log of export prove that the model is valid for the case of the Turkish economy. The estimated income elasticity of import is 2.605. The author concludes that the rise in income elasticity of demand for imports will adversely affect the positive effect of exports on GDP growth. Bértola, Higachi, and Porcile (2002) examine the model in Brazil. The authors find a long-run relationship between terms of trade, world income, and GDP. The authors show that the terms of trade coefficient is not statistically significant. Thus, they re-estimated the model without terms of trade, and they found a long run relationship between Brazilian real GDP and world income. Alencar and Strachman (2014) aim at verifying the applicability of the BOPCG model in Brazil using McCombie test. The result shows that the estimated income elasticity of import and a hypothetical income elasticity of import are not different. Therefore, the authors conclude that the balance of payments constrains economic growth in Brazil. Bajo-Rubio (2012) finds that Spain's GDP growth rate is slightly higher than the balance of payments constrained growth rate over the periods of 1850 to 1913 and 1940 to 2000. Felipe, McCombie, and Naqvi (2010) examine Thirlwall's model in Pakistan. The authors' statistical estimation show a value income elasticity of demand for import equal to 0.88 . This elasticity is not significantly different from a hypothetical income elasticity value of 0.91 . The authors indicate that Pakistan was approaching closely its balance of payments equilibrium growth rate. Razmi (2005) finds the predicted balance of payments constrained growth rate in India from 1950 to 1999 using the weak test was 3.85 percent. The strong version of the BOPCG model shows that the predicted growth rate is 4.11 percent. The author indicates that these two predicted growth values by the BOPCG model have indeed approached the actual average growth rate of the Indian economy, which reached 4.51 percent. Lanzafame (2014) examines Thirlwall's law in a panel consisting of twenty-two OECD countries. The author finds the BOPCG rate is the same as the average growth rate, which gives supportive evidence for Thirlwall's law. Soukiazis and Antunes (2011) find that on average Portugal's annual growth rate of national income for the whole analyzed period (1965-2008) exceeded the mean growth rate consistent with the balance of payments equilibrium, which results in a balance of payments deficit. Also, the McCombie test showed that the hypothetical income elasticity and the estimated income elasticity are statistically equal in Portugal. Leon-Ledesma (1999) finds that Thirlwall's model predicted Spain's actual growth rate from 1965 to 1993. Jeon (2009) shows that the average annual growth rate of the Chinese economy from 1979 to 2002 was $9.25 \%$. The hypothesis test revealed that this actual growth rate is statistically indifferent from the predicted growth rate by the balance of payments constrained growth model. Christopoulos and Tsionas (2003) examines Thirlwall's model in a panel of seven industrial countries consisting of Australia, France, Italy, Netherlands, Germany, 
the UK, and the USA over the period of 1960 to 1999. The results showed that the BOPCG model holds in these countries, except Australia. Bajo-Rubio and Díaz-Roldán (2009) compare the BOPCG rate with the actual growth rate in Central and Eastern European countries that became members of the EU in 2004. The authors find that Estonia, Latvia, Lithuania, Poland, Slovakia, Czech Republic and Slovenia grew higher than their balance of payments constrained growth rate. Conversely, the results showed that Hungary grew below its balance of payments growth rate. Guarini and Porcile (2016) extended Thirlwall's model by introducing a green Thirlwall's model. This green version allows environmental innovations to affect the rate of economic growth consistent with the equilibrium balance of payments constrained.

Gouvêa and Lima (2010) examine the original version and a multisector version of Thirlwall's model in Asian countries and Latin American countries over the period 1962-2006. The Latin American sample consists of Argentina, Brazil, Colombia, and Mexico. The Asian sample consists of South Korea, Malaysia, Philippines, and Singapore. The results show that the original version holds in all the sample countries, except South Korea. Moreover, the multi sector version was found to hold for all the selected sample. Jayme (2003) applies Thirlwall's model in Brazil using time series data from 1955 to 1998. The author found that GDP and export are cointegrated in the long run. Romero and McCombie (2016) conclude that the multi-sectoral Thirlwall's law holds in Austria, Denmark, Finland, France, Germany, Greece, Italy, Netherlands, Norway, Portugal, Spain, Sweden, Switzerland, and the UK. Nishi (2016) improved the multi-sectoral model by incorporating structural heterogeneity between sectors and countries. This structural heterogeneity includes differences in labor productivity, price competition, export and import share, and quality of commodities. Birkan (2017) examines the validity of the multi-sectoral Thirlwall's model in Turkey from 1962 to 2012. The author concludes that the multi-sectoral model is empirically valid in Turkey. Also, economic research applied the model in a sample of Central American countries, which consist of Costa Rica, El Salvador, Guatemala, Honduras, and Nicaragua (Moreno-Brid \& Pérez, 1999) and in Argentina (Chena, 2014; Alleyne \& Francis, 2008). All these studies concluded that the model predicted economic growth in the mentioned countries found that the Thirlwall's law is essential but not adequate condition for balanced long-run growth. To the author knowledge, Bairam (1990) is the only study that tested the model in oil exporting countries, including Saudi Arabia. The author concluded that the model does not hold in Saudi Arabia. However, the data of this paper is from the International financial statistics yearbook (1987). The author indicated that the statistics used are not entirely consistent or reliable. According to the author, measurement errors are very likely. The other shortcoming of this paper for Saudi Arabia's case is that the empirical conclusion is only based on 15 observations (1969-1984). Also, the study used OLS and the maximum likelihood method based on Cochrane-Orcutt procedure. Therefore, the study did not use the current advances in time series analysis. Analysis of time series data in economic literature state that running a regression on non-stationary data yields spurious results (Brooks, 2014). Therefore, this paper aims to reconsider Bairam's conclusion by using modern time series techniques.

\section{Empirical Model}

The paper follows economics literature, for example (Moreno-Brid, 2003; Jeon, 2009; Tharnpanich \& McCombie, 2013), in estimating the following traditional import demand function in the log- 
level form:

$$
\ln M=c+\pi \ln Y+\psi\left(P_{m} / P_{d}\right)
$$

Where $\mathrm{M}$ is the real import, $\mathrm{Y}$ is the average real domestic per capita income, $P_{d}$ is the domestic price index, and $P_{m}$ is the import price index. $\pi$ and $\psi$ are income elasticity and price elasticity of demand for import, respectively.

\section{Data}

As mentioned in the previous section that the variables of interest in this paper are imports, exports, income, domestic price, and import price. Imports are imported volume in a million Saudi Riyal, and exports are exported volume in a million Saudi Riyal. Income is the average individual income, domestic price is proxied by the local price index, and import price is proxied by import value index. The data is annual data from 1971 to 2014. The source of the data is from Saudi Arabian Monetary Agency (the central bank of Saudi Arabia) national statistics. Data for import value index comes from the World Bank. Observations for import value index from 1971 until 1979 are unavailable. Also, data for the domestic price index from 1971 to 1978 as well as in 2013 and 2014 are unavailable. Trend interpolation and extrapolation methods have been used in economic literature to predict missing observations by authors such as (Coelli, Rahman, \& Thirtle, 2003; Akkemik, 2009). Therefore, I used a linear trend extrapolation method to forecast the missing observations for the import value index and the domestic price index.

\section{Estimation Procedures and Empirical Results}

The paper follows the recent economic literature methodologies in the empirical analysis such as (Moreno-Brid, 2003; Jeon, 2009; Tharnpanich \& McCombie, 2013). The first procedure in the empirical analysis is a unit root test. The Augmented Dickey-Fuller test in Table 1 shows that all the variables are stationary at the first difference $\mathrm{I}(1)$.

Table 1

ADF Unit root test

\begin{tabular}{lrrrrrr}
\hline \multirow{2}{*}{ Variable } & \multicolumn{3}{c}{ Stationary at level } & \multicolumn{3}{c}{ First difference stationary } \\
\cline { 2 - 7 } & Zero Mean & Single Mean & Trend & Zero Mean & Single Mean & Trend \\
\hline Real Import & 3.270 & -2.590 & -2.450 & $-3.260^{* * *}$ & $-3.650^{* * *}$ & $-3.690^{* *}$ \\
Real Income & 0.970 & -2.380 & -2.380 & $-6.110^{* * *}$ & $-6.150^{* * *}$ & $-6.090^{* * *}$ \\
Relative price of import & -0.410 & -0.180 & -1.090 & $-3.860^{* * *}$ & $-4.190^{* * *}$ & $-4.130^{* *}$ \\
\hline$*, * *,{ }^{* * *}$ indicates statistically significant at $10 \%, 5 \%$ and $1 \%$, & respectively. & &
\end{tabular}

The second procedure in the empirical analysis is to find the optimal lag order. The preferred lag length as suggested by Akaike's information Criterion (AIC) in Table 2 is 3. However, corrected Akaike's information Criterion (AICC), Schwarz Bayesian information criterion (SBC), and Hannan-Quinn information criterion (HQC) indicate that two is the preferred lag order. Therefore, two has been selected as the lag length for subsequent analysis. 
Table 2

\begin{tabular}{lcccc}
\multicolumn{6}{l}{ Optimal lag length } \\
\hline Lag & AIC & AICC & SBC & HQC \\
\hline 0 & -8.275 & -8.262 & -8.032 & -8.185 \\
1 & -13.34 & -13.25 & -12.73 & -13.12 \\
2 & -14.17 & $-13.90^{*}$ & $-13.18^{*}$ & $-13.81^{*}$ \\
3 & $-14.26^{*}$ & -13.66 & -12.88 & -13.76 \\
\hline Note: * Denotes optimal lag order. Selection criteria \\
in the table are Akaike's information Criterion, \\
corrected Akaike's information Criterion, Schwarz \\
Bayesian information criterion, and Hannan-Quinn \\
information criterion, respectively
\end{tabular}

The next step is to determine the rank order, which helps determine the number of integrating vectors. Thus, the paper uses Johansen cointegration test for this purpose. The results of the Johansen cointegration analysis based on trace statistics and maximum eigenvalue test are shown in Table 3 and 4 . The results reject the null hypothesis of no cointegration at the five percent significance level based on (MacKinnon, Haug, \& Michelis, 1999).

Table 3

Johansen cointegration test based on trace statistics

\begin{tabular}{lccc}
\hline Null Hypothesis & Eigenvalue & Trace statistics & P-Value \\
\hline No Relationship & 0.537 & $46.78^{*}$ & 0.000 \\
More than One & 0.285 & 14.38 & 0.072 \\
More than Two & 0.006 & 0.264 & 0.606 \\
\hline * Rejection of the null hypothesis at the 5\% significance level.
\end{tabular}

Table 4

Johansen cointegration test based on Max statistics

\begin{tabular}{lccc}
\hline Null Hypothesis & Eigenvalue & Maximum & P-Value \\
\hline No Relationship & 0.537 & $32.39^{*}$ & 0.000 \\
More than One & 0.285 & 14.12 & 0.052 \\
More than Two & 0.006 & 0.264 & 0.606 \\
\hline * Rejection of the null hypothesis at the 5\% significance level.
\end{tabular}

Therefore, the variables are cointegrated in the long run. The maximum eigenvalue test and trace statistics show that the rank is one. The rank order is then used in the estimation of the vector error correction model (VECM). Table 5 shows the model diagnosis as well as the parameter estimates of the VECM.

The VECM was estimated with an intercept and a linear trend because the and the linear trend term were both significant at the one percent level. As indicated by Bértola et al. (2002) the deterministic trend reflects long-term changes in technological diffusion and international competitiveness. The results of diagnostic tests show no autocorrelation and no heteroskedasticity. The multicollinearity diagnosis indicates that the value of the variance inflation factor VIF is not more than 2.746 with a tolerance value of not less than 0.364 . Moreover, the condition index value did not exceed 2.978. These facts give an indication that the model does not suffer from collinearity problem.

The parameters stability were tested using cumulative sum (CUSUM) and the cumulative sum of squares (CUSUMSQ) tests. The plot of CUSUM and CUSUMSQ as appear in figure (a) and 
figure (b) show that the line of CUSUM and CUSUMSQ stay within the critical bounds at the 5 percent significance level.

Table 5

Parameter and model diagnostics

\begin{tabular}{|c|c|c|c|c|c|c|c|c|}
\hline \multirow[t]{2}{*}{ Variable } & \multirow[t]{2}{*}{ Estimate } & \multirow[t]{2}{*}{ Variable } & \multirow[t]{2}{*}{ Estimate } & \multirow[t]{2}{*}{ Variable } & \multicolumn{4}{|c|}{ Normality ARCH } \\
\hline & & & & & Chi-Square & $\mathrm{p}$ & F-Value & $\mathrm{p}$ \\
\hline $\mathrm{C}$ & $\begin{array}{c}-1.905^{* * *} \\
-0.400\end{array}$ & $\mathrm{t}$ & $\begin{array}{c}0.014^{* * *} * \\
-0.003\end{array}$ & $\operatorname{lm}$ & 1.980 & 0.371 & 0.850 & 0.362 \\
\hline$l m_{t-1}$ & $\begin{array}{l}-0.272 \\
-0.056\end{array}$ & $\Delta l m_{t-1}$ & $\begin{array}{c}0.599^{* *} \\
-0.221\end{array}$ & ly & 66.75 & $<.0001$ & 0.190 & 0.669 \\
\hline$l y_{t-1}$ & $\begin{array}{c}0.450 \\
-0.092\end{array}$ & $\Delta l y_{t-1}$ & $\begin{array}{c}-0.306^{* *} \\
-0.118\end{array}$ & $\operatorname{lrpm}$ & 5.380 & 0.068 & 0.270 & 0.604 \\
\hline $\operatorname{lrpm}_{t-1}$ & $\begin{array}{l}-0.133 \\
-0.027\end{array}$ & $\Delta l r p m_{t-1}$ & $\begin{array}{l}-0.226 \\
-0.278\end{array}$ & & & & & \\
\hline Durbin-Watson & & $\operatorname{lm}_{\operatorname{lrpm}}$ & $\begin{array}{l}1.840 \\
2.070 \\
1.910\end{array}$ & & & & & \\
\hline R-Square & & & 0.550 & & & & & \\
\hline
\end{tabular}

lm, ly, lrpm, and t denote the log of real import, log of real income, log of relative price of import,and linear trend. SAS software does not report the significance level and the t-value of long run parameters because they have non- Gaussian distributions ${ }^{* *}$ and ${ }^{* *}$ are respectively the significance level at $1 \%$ and $5 \%$. Standard error in parenthesis.

Therefore, the null hypothesis that all the parameters are stable is accepted. Also, the normality test shows that the residuals of all the variables are normally distributed, except for the $\log$ of real income. The null hypothesis of normality is rejected for the log of real income. This result is consistent with (Alencar \& Strachman, 2014) findings, who rejected the null hypothesis of normality for the log of real income for the import demand function. The estimated long-run income elasticity of demand for import $\pi$ is 1.657 , and the price elasticity of demand for import $\psi$ is -0.490 . The error correction term is negative and significant at the one percent level with a speed of convergence to equilibrium of 30 percent. The next step is to test whether or not the BOPCG model holds in Saudi Arabia. I use McCombie test (1989) which is to test if the estimated income elasticity and a hypothetical income elasticity are significantly different. The hypothetical income elasticity is calculated as below

$$
\pi_{h}=\frac{\bar{x}}{\bar{y}}
$$

Where the bar above the variables indicated average growth rate for real export and real income, respectively. Soukiazis and Antunes (2011) define the hypothetical income elasticity as "the income elasticity of demand for imports assuming equilibrium in the balance of payments or trade balance." The estimated hypothetical income elasticity is 1.640 . It is very clear that the hypothetical income elasticity is almost the same as the estimated income elasticity. The paper follows (Alencar \& Strachman, 2014; Britto \& McCombie, 2009) by using the value of the hypothetical income elasticity in hypothesis testing. The hypothesis testing involves imposing restrictions on the long-run cointegrating vector to examine if the estimated income elasticity is significantly different from the hypothetical income elasticity. Rejection of the null hypothesis of this test implies that Thirlwall's law holds in Saudi Arabia. The likelihood ratio test in Table 6 rejects the null hypothesis that the hypothetical and the estimated income elasticity are different. 


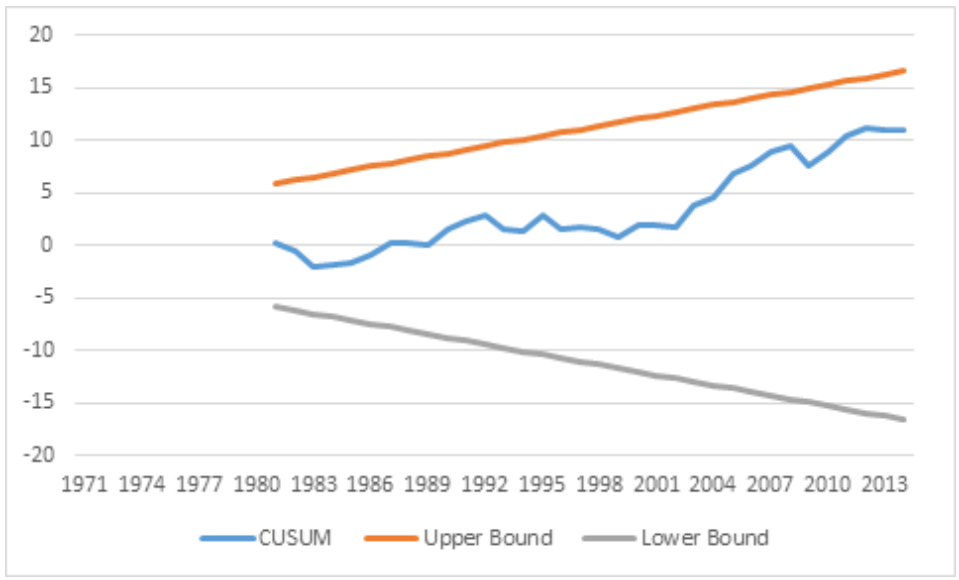

(a) $C U S U M$

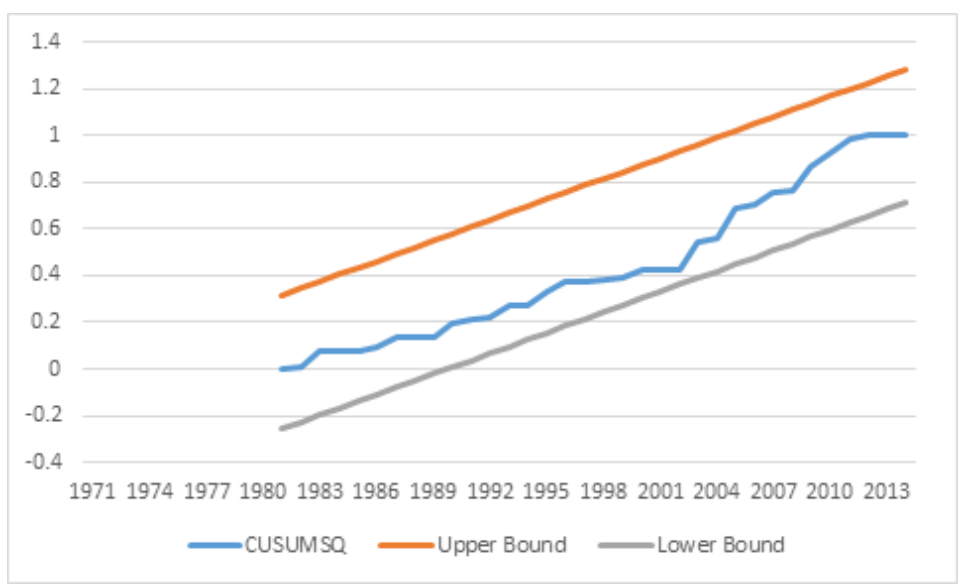

(b) $C U S U M Q$

Table 6

Likelihood ratio test on the estimated long-run income elasticity

\begin{tabular}{lcc}
\hline Restriction & Chi-Square & p \\
\hline$\pi=\pi_{h}$ & 0.01 & 0.993 \\
\hline$\pi$ denotes the hypothetical income elasticity &
\end{tabular}

The hypothetical income elasticity in equation (4) can be extended to include terms of trade effect (Tharnpanich \& McCombie, 2013) as below:

$$
\pi_{h}=\frac{\left(x+(1+\psi)\left(p_{d}-p_{f}-e\right)\right)}{\bar{y}}
$$


The estimated hypothetical income elasticity that includes terms of trade effect as expressed in equation (5) is 2.068. This value is also close to the income elasticity of demand for import, but it is not as close as the hypothetical income elasticity estimated using equation (4). The results of the likelihood ratio test (available on request) show that the hypothetical income elasticity that includes terms of trade effect is not significantly different from the estimated income elasticity (1.657).

Finally, Thirlwall's law validity in Saudi Arabia is verified by comparing the predicted growth rate consistent with BOPCG model and the actual growth rate of Saudi Arabia's real GDP. Figure 1 demonstrates that both the predicted BOPCG rate using the simple equation (1) and the real growth rate are close to each other. This result supports the validity of the BOPCG model in Saudi Arabia.

Table 7

Average annual actual growth rate VS predicted BOPCG rate

\begin{tabular}{|c|c|c|c|c|c|c|}
\hline Year & gGDP & Equation (1) & Equation (2) & (1)-gGDP & (2)-gGDP & CA Surplus \\
\hline 1971-2014 & 4.76 & 7.82 & 5.95 & 3.06 & 1.19 & 10.47 \\
\hline
\end{tabular}

Table 7 shows that the average annual GDP growth rate is 4.50 percent over the period of 1971-2014. The predicated growth rate by the simple BOPCG model in equation (1) is 7.28 percent. Moreover, the predicted growth rate by equation (2) that includes terms of trade effect is 5.95 percent. It is important to point out that the BOPCG rate that includes terms of trade effect is very close to the actual annual average growth rate. This implies that Saudi Arabia on average was growing below the growth rate consistent with its balance of payments equilibrium. Consequently, this enables Saudi Arabia to accumulate a balance of payments surplus. The average current account surplus as a ratio of GDP is 10.47 percent. The difference between actual growth rate and the growth rate consistent with the balance of payment model without the terms of trade effect is 3.06 percent. However, when terms of trade effect is considered, the difference is reduced to 1.19 percent. This shows that the average predicted growth rate by the BOPCG model has indeed approximated the actual growth rate of the Saudi economy.

Based on the framework of this study, the paper recommends to the decision-makers in Saudi Arabia to lower the income elasticity of demand for import and raise exports. Since Saudi Arabia is one of the world's largest oil, petrochemicals and petroleum related products producer, the increase in exports can be done by creating industries that turn these raw products into final products. Saudi Arabia currently exports the raw products and later imports the final product. Thus, policy makers in the Saudi government should support, facilitate, and encourage industries that utilize the country's natural resources, which can reduce the reliance on imports and increase export. Also, the paper recommends to the Saudi government to develop promising sectors such as tourism and manufacturing sectors. Also, Saudi Arabia is currently of the largest country in the world concerning importing and spending on military equipment. The development of tourism sector can be done by facilitating visa process and supporting companies working in the tourism sector. The development of manufacturing sector can help achieve the recommendation of this paper by creating local industries than can produce products that utilize local resources. To achieve this purpose, the government has launched recently a new vision that aims to induce social, political, and economic growth in Saudi Arabia. Thus, it is important to discuss Saudi Arabia's 2030 vision since most of the recommendations of this paper are in line with the new 
vision of the Saudi government.

\section{Saudi Arabia's 2030 Vision and its Objectives}

The primary target of this section is to provide an overview of Saudi Arabia's new vision and to discuss how it is going to contribute to the economic growth and the development of Saudi Arabia. Saudi Arabia has launched a future vision called 2030 vision. The Saudi government announced this vision on 25 April 2016. This vision aims primarily at diversifying the Saudi economy and decreasing the country's reliance on oil as the primary driver of economic growth. The Saudi government stated that this vision is based on three themes which are vibrant society, thriving economy, and ambitious nation. The first theme focuses on corroborating national identity, patriotism, and creating homogeneous social and health care systems. This theme also aims to maintain Islamic identity by offering a welcoming, safe, and responsible environment to all Muslims around the world visiting Saudi Arabia for religious purposes such as performing Umrah and Hajj. Also, in this theme, the government aims to increase entertainment and tourism sites as well as increasing citizens, residents, and visitors' awareness about healthy lifestyle and healthy food selections. Moreover, the government in this theme aims to establish environmental sustainability programs that preserve natural resources, reduce pollution, and utilize recycling. The second theme focuses on building applied education system tailored to job market's needs, supporting entrepreneurship, creating employment opportunity, privatization to improve services quality and create a diverse economy. Under this theme, the government intends to review its energy subsidies program to both individuals and corporations. The Saudi government in this vision aims to grant subsidies based on meeting certain established criteria. The government stated that reducing subsidies for corporates working in the energy sector will, in the long run, increase their productivity and competitiveness.

Also, creating a renewal energy system in Saudi Arabia is one of the government's priorities in this theme. The government in this theme intends to develop telecommunication and information technology sector. Diversifying the country's revenue and investment is stated under the second theme. The diversification strategy is based on making the Saudi investment fund on of the largest investment fund in the world by transferring Saudi Aramco ownership to the Saudi investment fund. Also, the government aims to acquire assets and invest in local and global companies through the Saudi investment fund. By adopting this strategy, the Saudi government hopes to be one of the world's key play in equity and debt market. In this theme, the government intends to develop promising sectors such as tourism and manufacturing sectors. The development of these sectors is in line with the recommendation of this paper. Since Saudi Arabia is one of the largest countries in the world regarding military spending, the government intends to create new military factories and expand its current military factors to reduce its military imports and become an independent country in the military sector. In addition, Saudi Arabia has many areas with rich mineral resources such as aluminum, phosphate, gold, and copper. Thus, under the second theme, the government plans to expand the mining sector to increase its contribution to the gross domestic product and in the labor market by creating new employment opportunities.

The third theme concentrates on increasing efficiency, productivity, transparency, and responsibility in the government sector. The Saudi government under this theme hopes to raise the productivity of public sectors' employees and to offer them state-of-the-art learning resources to increase their skills and competencies. The government wishes to eliminate corruption and to implement a zero tolerance policy against corruption. Additionally, the government aims to eliminate or reduce waste whether it is a financial waste, resource waste, or efforts waste. To reduce waste in efforts and to increase government performance, the Saudi government plans to switch 
to an electronic government (e-government) by enabling most of the governmental transactions to be done in an automated way. Also, this theme intends to make citizens, the private sector, and not for profit sectors to be accountable, prepared to face challenges, and utilize prominent opportunities. The government made a clear statement under this theme that it intends not to place an income tax on citizens, on wealth, or on essential goods.

In order to achieve the objective of this vision, the Saudi government has mentioned many steps it intends to take to pave the way for vision implementation. The most important steps the government contemplating to implement are:

1. To restructure the government in order to facilitate decision-making process and reduce bureaucracy.

2. To expose decision-making process and performance in the government sector subject to benchmarking, evaluation, and create key performance indicators.

3. To improve project management consultancy, evaluation, and implementation.

4. To revise existing laws in Saudi Arabia by enhancing, adjusting, or retracting unnecessary regulations.

5. To restructure Saudi Arabian Oil Company (Saudi Aramco) and the public investment funds by diversifying their activities and investments.

6. To increase public-private partnership locally and globally.

In line with Saudi Arabia's new vision; the Saudi government has launched two programs to accompany the 2030 vision. The first program is the national transformation program and the second program is the fiscal balance program. The Saudi government considers these two programs as the prerequisite for the implementation of its 2030 vision. The national transformation program has started in mid-2016 and is planned to reach its maturity in 2020. Many governmental agencies, units, and centers are involved in this program. The objectives of the national transformation program are as follow:

A. To identify strategic goals and barriers against achieving those goals.

B. To convert the strategic goals into initiatives. The initiatives are then become plans, and the plans are put into action.

C. To increase employment opportunities in non-governmental sectors.

D. To increase private sector involvement and contribution in the gross national income and the gross domestic product, respectively.

E. To decrease the country's dependency on imports by producing goods locally. This objective is consistent with Thirlwall's model that states if a country wants to grow faster it needs to increase its export and reduce its income elasticity of demand for imports.

F. To increase harmony, coordination, and communication among various governmental sectors and agencies.

Implementing the national transformation program and subsequently, the 2030 vision requires costs. Thus, the government has created the fiscal balance program. Due to the fact that the Saudi government finances its spending primarily from oil revenue and oil prices are volatile in nature, the government launched the fiscal balance program. The aim of this program is to reduce the budget deficit, especially in periods of declining oil prices. When oil prices plunged in 2016, 
the Saudi government has taken many actions to reduce the budget deficit and to rationalize government's expenditures.

The major actions that were taken by the government include reductions in public sector employees' allowance and benefits, suspension of annual salary increase, raising energy prices, raising water prices, and rising electricity tariffs. The increase in energy, water, and electricity tariffs was placed on households and corporate users. The intended outcomes of fiscal balance program are to grow non-oil revenues, reduce governmental capital and operational expenditures, reduce governmental subsidies by giving them to low-income citizens, maintain economic growth in the private sectors, and increase taxes and fees on foreign residents. The government did not consider the consequences of increasing fees and taxes on foreign workers. If fees are to be raised on foreign residents, the services cost rendered by them will increase.

Thus, the Saudi government should keep in mind price transmission before placing further fees and taxes on foreign workers. Furthermore, since many sectors in Saudi Arabia are run by foreign workers, putting extra fees on foreign workers will force some of them to leave Saudi Arabia and return home or seek employment opportunities elsewhere because the working environment in Saudi Arabia will no longer be a rewarding environment. This will result in a shortage of the workforce, especially in the private sector, because foreign workers occupy jobs that are difficult to be replaced by citizens with comparable skills. Also, the real estate sector will be affected negatively by the increase in fees on expat because expats workers rent many units in Saudi Arabia, and when they leave Saudi Arabia, the demand for a rental apartment will be impacted negatively. These are some adverse outcomes of raising fees on expat workers, and future studies should conduct a comprehensive analysis on the impact of Saudi Arabia's new vision of raising taxes on expat workers and the Saudi economy.

\section{Conclusion}

This paper examined Thirlwall's BOPCG model in Saudi Arabia. The Johansen cointegration indicated that real import, real income, and the relative price of import are cointegrated in the long run. In order to empirically test the BOPCG model, the paper estimated an import demand function using a vector error correction model. The results showed that Saudi Arabia has an elastic income elasticity and an inelastic price elasticity of demand for import. To verify whether or not the BOPCG model holds in Saudi Arabia, the paper used McCombie test by comparing the estimated income elasticity with a hypothetical income elasticity. A quick look on the estimated income elasticity $(\pi=1.657)$ and the hypothetical income elasticity without terms of trade effect $\left(\pi_{h}=1.640\right)$ clearly shows that they are the same. Furthermore, the likelihood ratio test rejected the hypothesis that the estimated income elasticity and the hypothetical income elasticity are significantly different. Also, the hypothetical income elasticity that includes terms of trade effects is not significantly distinct from the estimated income elasticity of demand for import. Besides, the graphical illustration showed that the predicted growth rate by the BOPCG model was a very good predictor of Saudi Arabia's real GDP growth. Indeed, the BOPCG rate that includes terms of trade effect is 5.95, and average Saudi Arabia's actual GDP growth rate is 4.76. Therefore, the study concludes that Saudi Arabia on average was growing below the growth rate in accordance with the balance of payments equilibrium. This paper recommends for future research to conduct multi-sectoral Thirlwall's model in Saudi Arabia to examine if the model holds in the oil sector and other sectors. 


\section{References}

Akkemik, K. A. (2009). Cost function estimates, scale economies and technological progress in the Turkish electricity generation sector. Energy Policy, 37(1), 204-213.

Alencar, D. A., \& Strachman, E. (2014). Balance-of-payments-constrained growth in Brazil: 1951-2008. Journal of Post Keynesian Economics, 36(4), 673-698.

Alleyne, D., \& Francis, A. A. (2008). Balance of payments-constrained growth in developing countries: A theoretical perspective. Metroeconomica, 59(2), 189-202.

Atesoglu, H. S. (1993). Balance-of-payments-constrained growth: Evidence from the United States. Journal of Post Keynesian Economics, 15(4), 507-514.

Atesoglu, H. S. (1997). Balance-of-payments-constrained growth model and its implications for the United States. Journal of Post Keynesian Economics, 19(3), 327-335.

Bairam, E. (1990). The Harrod foreign trade multiplier revisited. Applied Economics, 22(6), 711-718.

Bajo-Rubio, O. (2012). The balance-of-payments constraint on economic growth in a long-term perspective: Spain, 1850-2000. Explorations in Economic History, 49(1), $105-117$.

Bajo-Rubio, O. (2014). Balance-constrained growth rates: generalizing Thirlwall's law. Applied Economics Letters, 21 (9), 593-596.

Bajo-Rubio, O., \& Díaz-Roldán, C. (2009). Does the balance of payments constrain economic growth? Some evidence for the new EU members. Post-Communist Economies, 21(1), 41-46.

Barbosa-Filho, N. H. (2012). The balance-of-payments constraint: From balanced trade to sustainable debt. PSL Quarterly Review, 54(219), 384-400.

Bértola, L., Higachi, H., \& Porcile, G. (2002). Balance-of-payments-constrained growth in Brazil: A test of Thirlwall's Law, 1890-1973. Journal of Post Keynesian Economics, $25(1), 123-140$.

Birkan, A. Ö. (2017). Technological structure of trade and BOP-constrained growth in Turkey. The Journal of International Trade $\mathcal{E}$ Economic Development, 1-25. doi: 10.1080/09638199.2016.1274333

Britto, G., \& McCombie, J. S. (2009). Thirlwall's law and the long-term equilibrium growth rate: An application to Brazil. Journal of Post Keynesian Economics, 32(1), $115-136$.

Brooks, C. (2014). Introductory econometrics for finance. Cambridge University Press.

Chena, P. I. (2014). Balance-of-payments-constrained growth in Argentina (1976-2006). Journal of Post Keynesian Economics, 36(4), 699-718.

Christopoulos, D. K., \& Tsionas, E. G. (2003). A reassessment of balance of payments constrained growth: Results from panel unit root and panel cointegration tests. International Economic Journal, 17(3), 39-54.

Coelli, T., Rahman, S., \& Thirtle, C. (2003). A stochastic frontier approach to total factor productivity measurement in Bangladesh crop agriculture, 1961-92. Journal of International Development, $15(3), 321-333$.

Felipe, J., McCombie, J., \& Naqvi, K. (2010). Is Pakistan's growth rate balance-ofpayments constrained? Policies and implications for development and growth. Oxford 
Development Studies, 38(4), 477-496.

Garcimartin, C., Alonso, J. A., \& Rivas, L. (2014). Balance-of-payments-constrained growth and convergence: One more piece of the jigsaw. Journal of Post Keynesian Economics, 36(3), 555-585.

Garcimartin, C., Kvedaras, V., \& Rivas, L. (2016). Business cycles in a balance-ofpayments constrained growth framework. Economic Modelling, 57(3), 120-132.

Gökçe, A., \& Çankal, E. (2013). Balance-of-payments constrained growth model for the Turkish economy. Economic Modelling, 35(2), 140-144.

Gouvêa, R. R., \& Lima, G. T. (2010). Structural change, balance-of-payments constraint, and economic growth: Evidence from the multisectoral Thirlwall's law. Journal of Post Keynesian Economics, 33(1), 169-204.

Guarini, G., \& Porcile, G. (2016). Sustainability in a post-Keynesian growth model for an open economy. Ecological Economics, 126(1), 14-22.

Halicioglu, F. (2012). Balance-of-payments-constrained growth: The case of Turkey. Journal of Post Keynesian Economics, 35(1), 65-78.

Hieke, H. (1997). Balance-of-payments-constrained growth: A Reconsideration of the Evidence for the US economy. Journal of Post Keynesian Economics, 19(3), 313325.

Jayme, F. (2003). Balance-of-payments-constrained economic growth in Brazil. Brazilian Journal of Political Economy, 23(1), 62-84.

Jeon, Y. (2009). Balance-of-payment constrained growth: The case of China, 1979-2002. International Review of Applied Economics, 23(2), 135-146.

Lanzafame, M. (2014). The balance of payments-constrained growth rate and the natural rate of growth: New empirical evidence. Cambridge Journal of Economics, 38(4), $817-838$.

Leon-Ledesma, M. A. (1999). An application of Thirlwall's Law to the Spanish economy. Journal of Post Keynesian Economics, 21 (3), 431-439.

MacKinnon, J. G., Haug, A. A., \& Michelis, L. (1999). Numerical distribution functions of likelihood ratio tests for cointegration. Journal of Applied Econometrics, 14 (5), $563-577$.

McCombie, J. S. (1992). 'Thirlwall's Law'and balance of payments constrained growth: More on the debate. Applied Economics, 24 (5), 493-512.

Moreno-Brid, J. C. (2003). Capital flows, interest payments and the balance-of-payments constrained growth model: A theoretical and empirical analysis. Metroeconomica, $54(2-3), 346-365$.

Moreno-Brid, J. C., \& Pérez, E. (1999). Balance-of-payments-constrained growth in Central America: 1950-96. Journal of Post Keynesian Economics, 22(1), 131-147.

Nishi, H. (2016). A multi-sectoral balance-of-payments-constrained growth model with sectoral heterogeneity. Structural Change and Economic Dynamics, 39(2), 31-45.

Razmi, A. (2005). Balance-of-payments-constrained growth model: The case of India. Journal of Post Keynesian Economics, 27(4), 655-687.

Romero, J. P., \& McCombie, J. S. (2016). The multi-sectoral Thirlwall's law: Evidence from 14 developed European countries using product-level data. International Review of Applied Economics, 30(3), 301-325. 
Soukiazis, E., \& Antunes, M. (2011). Application of the balance-of-payments-constrained growth model to Portugal, 1965-2008. Journal of Post Keynesian Economics, 34 (2), 353-380.

Soukiazis, E., Cerqueira, P. A., \& Antunes, M. (2014). Explaining italy's economic growth: A balance-of-payments approach with internal and external imbalances and nonneutral relative prices. Economic Modelling, 40(2), 334-341.

Tharnpanich, N., \& McCombie, J. S. (2013). Balance-of-payments constrained growth, structural change, and the Thai economy. Journal of Post Keynesian Economics, $35(4), 569-598$.

Thirlwall, A. P. (2011). Modelli di crescita limitata dalla bilancia dei pagamenti: storia e panoramica (balance of payments constrained growth models: history and overview). doi: 10.1057/9781137023957_2

Thirlwall, A. P., \& Hussain, M. N. (1982). The balance of payments constraint, capital flows and growth rate differences between developing countries. Oxford Economic Papers, 34(3), 498-510. 